\title{
IMPLEMENTATION OF DSS USING REGRESSION ANALYSIS FOR DAM MANAGEMENT
}

\author{
Omkar Potekar ${ }^{1}$, Siddharth Roman $^{2}$, Swapnil Dhumal $^{3}$, Akshay Dhadave ${ }^{4}$, Pratap Singh Solanki ${ }^{5}$ \\ ${ }^{1,2,3,4}$ Student, Zeal College of Engineering and Research, Pune, Maharashtra, India \\ ${ }^{5}$ Scientist B, C.W.P.R.S., Pune, Maharashtra, India
}

\begin{abstract}
Reservoirs created behind the dam on a river are meant for the storage of water which can be utilized for the purpose of irrigation, drinking water, power generation, industrial use, recreation etc. Besides fulfilling the requirement of the society, these reservoirs also helps in mitigation of floods during heavy rainfall in the catchment. The releases through reservoir for various purposes are controlled by gates. The decision to operate the gates is taken on the basis of observation of discharge at immediate upstream gauging site as per prevailing practice. The warning time to reach the water from these sites to reservoir called 'inflow, is generally few hours depending upon the 'time of travel' of discharge from upstream site to the reservoir. In the event of very high rainfall for consecutive days it sometimes become difficult to accommodate and manage the large quantum of water reaching the dam site even with full opening of gates. This leads to catastrophic floods in downstream of reservoir. This calls for an efficient warning system having advance warning of inflow coming to reservoir so that regulated supply through gates could be released in advance to accommodate the incoming flood. An attempt is therefore made to develop an advance warning system with $\boldsymbol{C \# ~ b a s e d ~ o n ~ d a t a ~ m i n i n g ~ t o o l s . ~ T h i s ~ p a p e r ~ d e s c r i b e ~ t h e ~ u s e ~ o f ~ r e a l ~ t i m e ~ h i s t o r i c a l ~ r a i n f a l l ~ d a t a ~ t o ~ f i r s t ~ p r e d i c t ~ d i s c h a r g e s ~ a t ~}$ two upstream siteswhich in turn used to predict real time inflow into the reservoir three days in advance. In order to develop a dedicated computer program for this warning system the data of a typical dam in Maharashtra, India, on the confluence of two rivers is utilized. It is found that the predictions made with the developed program were 75 to $86 \%$ correct and thus can be successfully utilized to control the gates and in turn will save the mankind from the danger of flash floods.
\end{abstract}

Keywords: DSS, Regression Analysis, Hatnur Dam, Dam Management

\section{INTRODUCTION}

A Decision Support System (DSS) is a computerbased information system that supports business or organizational decision-making activities. DSSs serve the management, operations, and planning levels of an organization (usually mid and higher management) and help people make decisions about problems that may be rapidly changing and not easily specified in advance-i.e. Unstructured and Semi-Structured decision problems. Decision support systems can be either fully computerized, human-powered or a combination of both.

While academics have perceived DSS as a tool to support decision making process, DSS users see DSS as a tool to facilitate organizational processes. Some authors have extended the definition of DSS to include any system that might support decision making. Characteristics of DSS are:

i) DSS tends to be aimed at the less well structured, underspecified problem that upper level managers typically face;

ii) DSS attempts to combine the use of models or analytic techniques with traditional data access and retrieval functions;

iii) DSS specifically focuses on features which make them easy to use by non-computer people in an interactive mode; and iv) DSS emphasizes flexibility and a daptability to accommodate changes in the environment and the decision making approach of the user.

DSSs include knowledge-based systems. A properly designed DSS is an interactive software-based system intended to help decision makers compile useful information from a combination of raw data, documents, and personal knowledge, or business models to identify and solve problems and make decisions[1].Before implementing any DSS it needs to be tested and validated to assure its functionality and features. Number of expert system available for simulating real world problems of hydrology and Dam Engineering can be seen in [2]. Authors in this work attempted to develop a DSS based on data mining.

\subsection{Study Area}

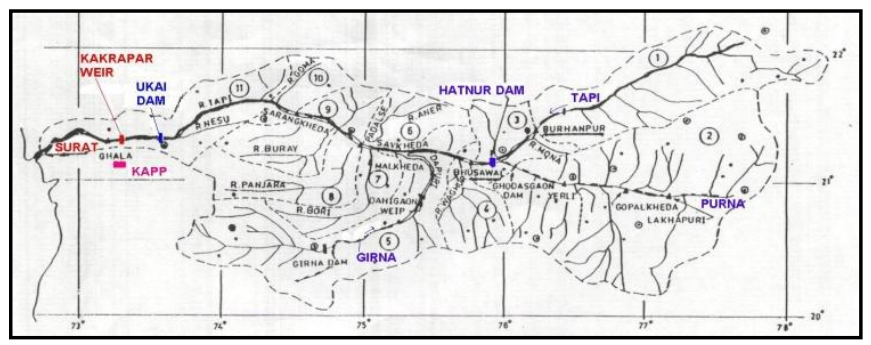

Figure 1.1 Hathnur Dam and its catchment 
Hatnur Dam(Figure 1.1) is taken as primary study area for implementation of DSS. The various features [3] of Hathnur Reservoir are shown in Table 1.1below.

\begin{tabular}{|c|c|c|c|}
\hline \multirow{2}{*}{\begin{tabular}{|l|}
\multicolumn{1}{|c|}{ Table 1.1} \\
$\begin{array}{l}\text { Name of the } \\
\text { Dam }\end{array}$ \\
\end{tabular}} & \multicolumn{3}{|c|}{ Salient Features of Hatnur Dam } \\
\hline & Hahtnur Dam & $\begin{array}{l}\text { Length of Dam } \\
\text { (m) }\end{array}$ & 2580 \\
\hline River & Tapi & $\begin{array}{l}\text { Max Height } \\
\text { above } \\
\text { Foundation }(\mathrm{m})\end{array}$ & 25.5 \\
\hline Nearest City & Bhusawal & Type of Spillway & OG \\
\hline District & $\begin{array}{l}\text { Jalgaon, } \\
\text { Maharashtra }\end{array}$ & $\begin{array}{l}\text { Type of Spillway } \\
\text { Gates }\end{array}$ & RADIAL \\
\hline Basin Name & Tapi & $\begin{array}{l}\text { Number of } \\
\text { Spillway Gates }\end{array}$ & 41 \\
\hline Purpose & \begin{tabular}{|l|} 
Irrigation and \\
Power
\end{tabular} & \begin{tabular}{|l} 
Length of \\
Spillway (m)
\end{tabular} & 604.75 \\
\hline Dam Type & $\begin{array}{l}\text { Earthen with } \\
\text { concrete } \\
\text { spillway } \\
\end{array}$ & $\begin{array}{l}\text { Crest Level of } \\
\text { Spillway }\end{array}$ & 205 \\
\hline $\begin{array}{l}\text { Completion } \\
\text { Year }\end{array}$ & 1982 & $\begin{array}{l}\text { Spillway } \\
\text { Capacity }\left(\mathrm{m}^{3} / \mathrm{s}\right)\end{array}$ & 26415 \\
\hline $\begin{array}{l}\text { Full } \\
\text { Reservoir } \\
\text { Level (m) } \\
\end{array}$ & 214 & $\begin{array}{l}\text { Gross Storage } \\
\text { Capacity(Mm3) }\end{array}$ & 388 \\
\hline $\begin{array}{l}\text { Minimum } \\
\text { Draw Down } \\
\text { Level }(\mathbf{m}) \\
\end{array}$ & 209 & $\begin{array}{l}\text { Dead Storage } \\
\text { Capacity }\left(\mathbf{M m}^{3}\right)\end{array}$ & 133 \\
\hline
\end{tabular}

Hatnur dam is divided in 3 catchments:

1.Burhanpur 2.Yerli 3.Intervening catchment between Yerli and Burhanpur.

Rain gauges in each catchment:

(A) Burhanpur

* Multai, Madhya Pradesh (R1)

* Athner, Madhya Pradesh (R2)

* Burhanpur, Madhya Pradesh (R3)

(B) Yerli

* Bhainsdehi, Madhya Pradesh (R4)

* Amravati, Maharashtra (R5)

* Chikhaldara, Maharashtra (R6)

* Anjangaon, Maharashtra (R7)

* Akola, Maharashtra (R8)

* Telhara, Maharashtra (R9)

* Shegaon, Maharashtra (R10)

* Nandura, Maharashtra (R11)

* Yerli, Maharashtra (R12)
(C) Intervening Catchment between Yerli and Burhanpur

* Buldhana, Maharashtra (R13)

* Edlanad, Maharashtra (R14)

* Shirpur, Maharashtra (R15)

* Raver, Maharashtra (R16)

There are total 16 rain gauges for Hathnur Catchment.

\subsection{Implementation}

Here we have implemented the DSS for Dam Management using C\# .NET Framework. The system is tested and validated against the 10 years data available for Hathnur Dam. The system(Figure 1.2) is capable of

$>$ Suggesting Decisions

$>$ Predicting Inflow

$>$ Sending Alerts via E-Mail(Figure 1.3)

$>$ Generating Reports(Figure 1.4)

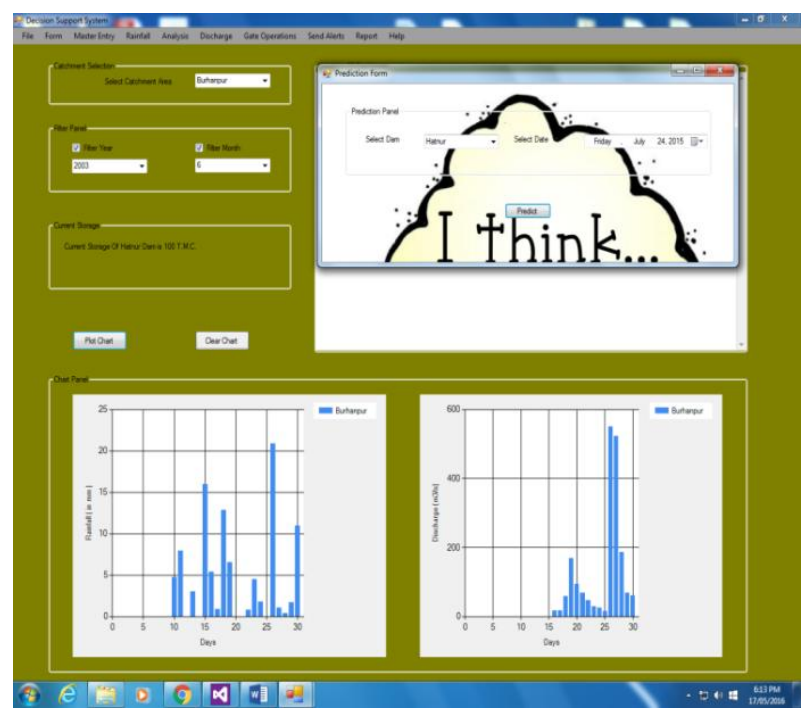

Figure 1.2 Main form and Predictor form

The predicted v/s observed discharge analysis template is shown as Figure 1.5. Rainfall information form is shown as Figure 1.6.

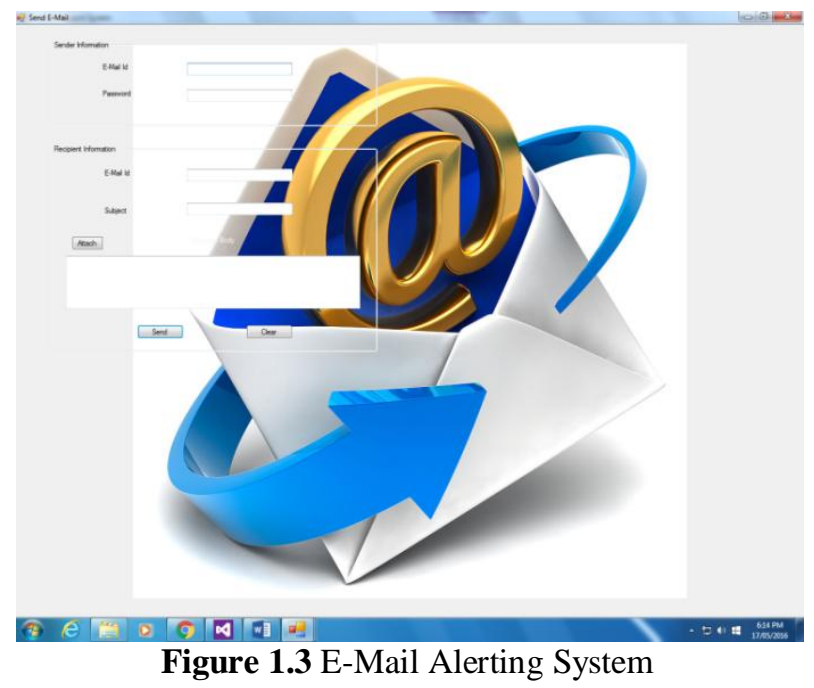




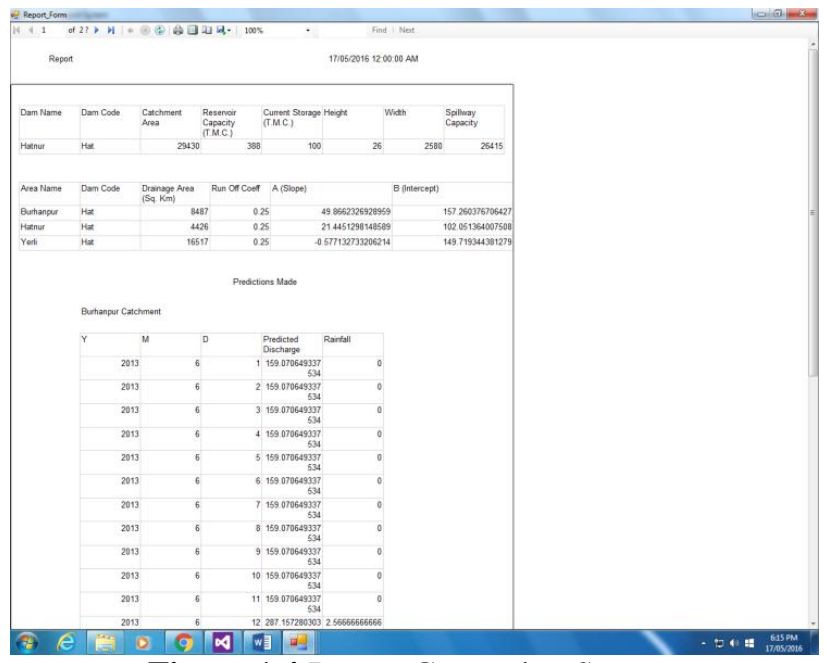

Figure 1.4 Report Generating System

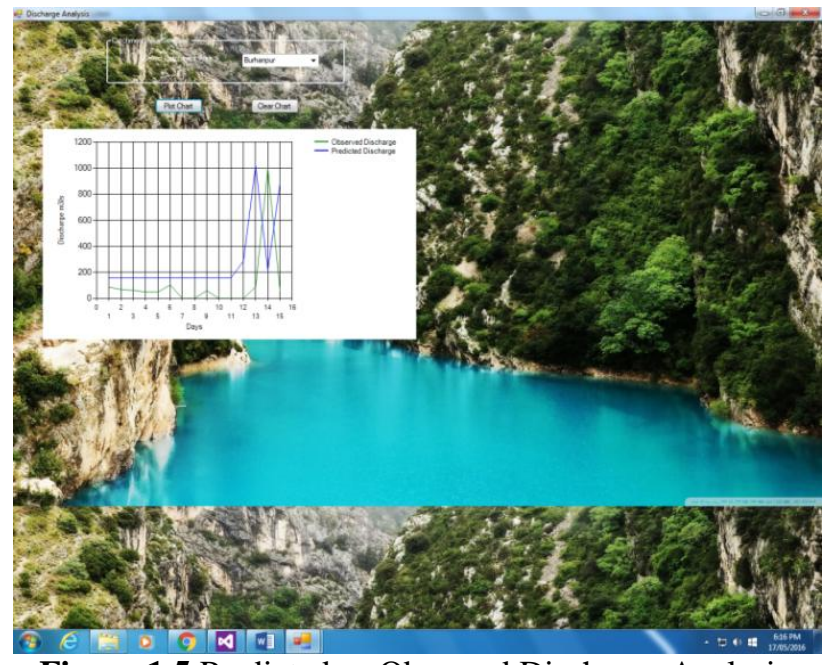

Figure 1.5 Predicted vs Observed Discharge Analysis

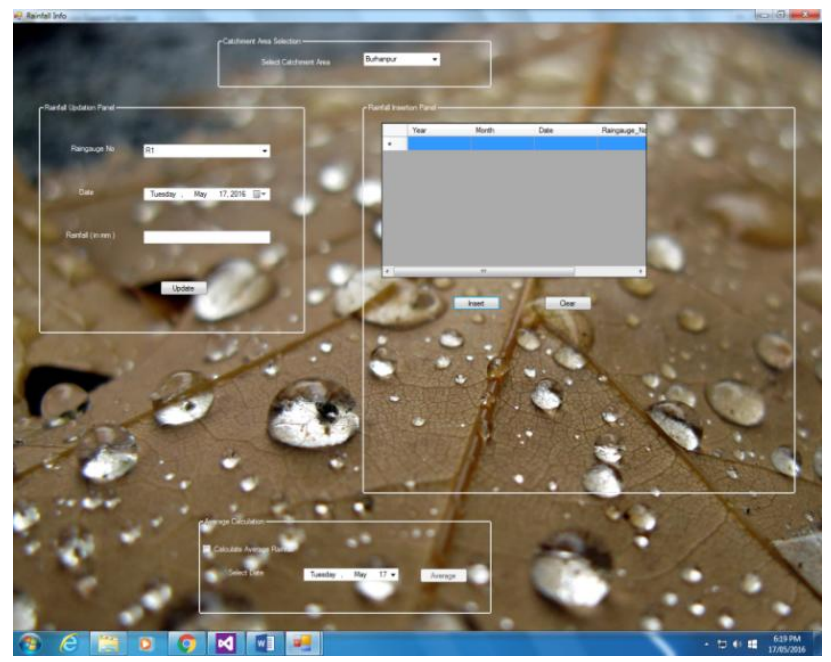

Figure 1.6 Rainfall Info Form

\section{Regression Analysis for Inflow Prediction}

\section{(Verification and Validation)}

Rainfall-Runoff models were developed in the past which play an important role in the operation and design of an hydraulic systems. These models attempt to simulate the complex hydrological processesthat lead to the transformation of rainfall into runoff with varying degree of abstraction from these physical processes [4]There are number of methods, models [5] and programs generated by various researchers for prediction of Runoff/ discharge/ Inflow due to rainfall but very few are reported to have simultaneous prediction of discharge as well as Inflow into a reservoir. In this work the objective was to develop a program to integrate the data supplied by field civil Engineers to simulate with known discharge series so as to generate a robust program for future predictions of discharge as well as Inflow. Therefore for prediction purpose the simple linear equation is used to avoid complexities of nonlinear equations as the main focus was to synchronize the data from various locations in a catchment. Much emphasis was given at how to utilize data mining in the simultaneous prediction of discharge at two sites Burhanpur and Yerli and apply the results to predict inflow for control of gates of Hathnur dam in real time system. The program provides systematic approach for regulated supply of water released through Hathnur dam so that the reservoir neither deprived of the required annual capacity nor will create havoc of flood downstream.

\subsection{Discharge Prediction at Burhanpur}

There are three rain gauge stations in Burhanpur catchment viz., Multai, Atner and Burhanpur. Ten years of monsoon rainfall data from Year 2003 to Year 2012 and corresponding discharges at Burhanpur were taken to generate the regression equation for Burhanpur Catchment. It was necessary to keep in mind that when rain falls at remotest part of the catchment it takes time to reach the outlet of catchment due to interception in vegetation, structures etc., Percolation in the ground and evaporation in the atmosphere. Thus water moves slowly in the catchment, reaches the river and then quickly moves towards outlet. Therefore before establishing the rainfall- discharge regression equation, the daily rainfall series with no lag, one day lag, two day lag and three day lag as compared to daily discharge was checked as shown.

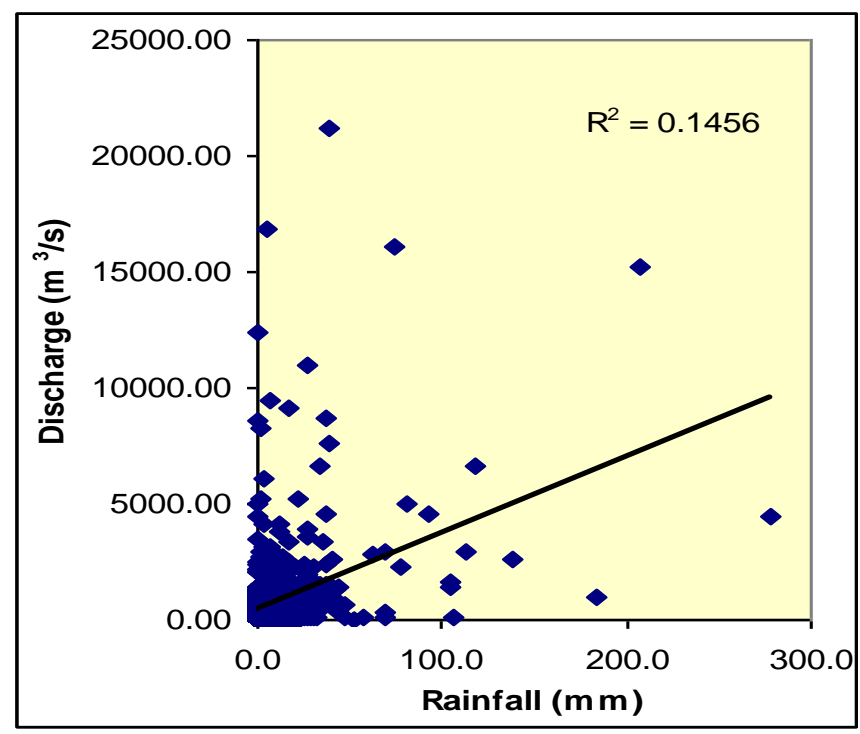

(a) 


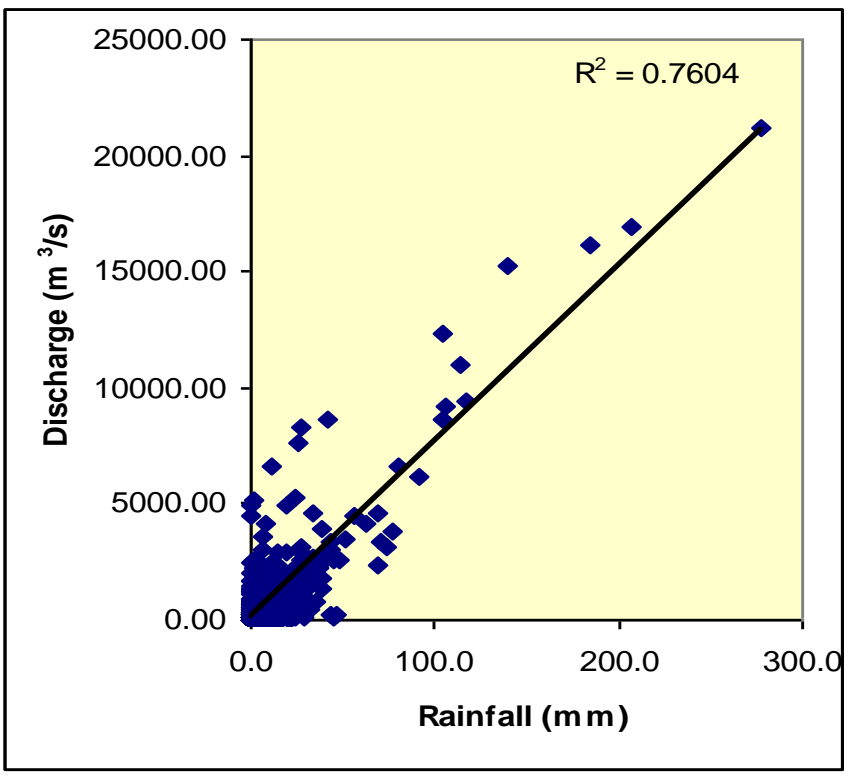

(b)

Figure 2.1: Response of Burhanpurcatchment at Burhanpur gauging Site due to rainfall lconsidering (a) no lag (b) one day lag

As could be seen that the rainfall data in Burhanpur catchment best matches with the discharge data at Burhanpur with one day lag (Figure 2.1 b) having coefficient of correlation $\left(\mathbf{R}^{2}\right)=\mathbf{0 . 7 6}$ It means whenever rainfall occurs in Burhanpur catchment at all three stations Multai, Atner and Burhanpur on any previous day (d-1), its effect will be on next day (d). The regression equation thus generated for this set of datafor Burhanpurcatchment considering one day lag will be represented as

$Q_{\mathrm{B} 2}=75.492 *\left(\left(R_{\mathrm{m} 1}+R_{\mathrm{a} 1}+R_{\mathrm{b} 1}\right) / 3\right)+110.99$

Where $\mathbf{R}_{\mathbf{m} 1}, \mathbf{R}_{\mathbf{a} 1}, \mathbf{R}_{\mathbf{b} \mathbf{1}}$ representsrainfall at Multai (m), Atner (a) and Burhanpur (b) rain gauge stations on $1^{\text {st }}$ day while $\mathrm{Q}_{\mathrm{B} 2}$ represent discharge at Burhanpur on $2^{\text {nd }}$ day. The above equation is fed to the program and the same is used to predict discharges at Burhnapur for the monsoon period of year 2013. The results of the same were validated with the known values of measured discharges. Predictions were made from $1^{\text {st }}$ June to $30^{\text {th }}$ September of the year 2013. It could be observed from Figure 1.2 that the results of discharges so generated by the program gives nearly $86 \%$ correct.

Comparison of predicted and observed discharges at Burhanpur is also shown as real time flow diagram as Figure 2.3 The graph clearly shows that the pattern of predicted and Observed discharges at Burhanpur is in close association of each other with one day lag. It meansfor example we can see from the graph at Figure 2.3 that we have predicted peak discharge of $10332 \mathrm{~m} 3 / \mathrm{s}$ on $28^{\text {th }}$ July 2013 which actually occurred on $29^{\text {th }}$ July 2013 with 11884 $\mathrm{m} 3 / \mathrm{s}$.

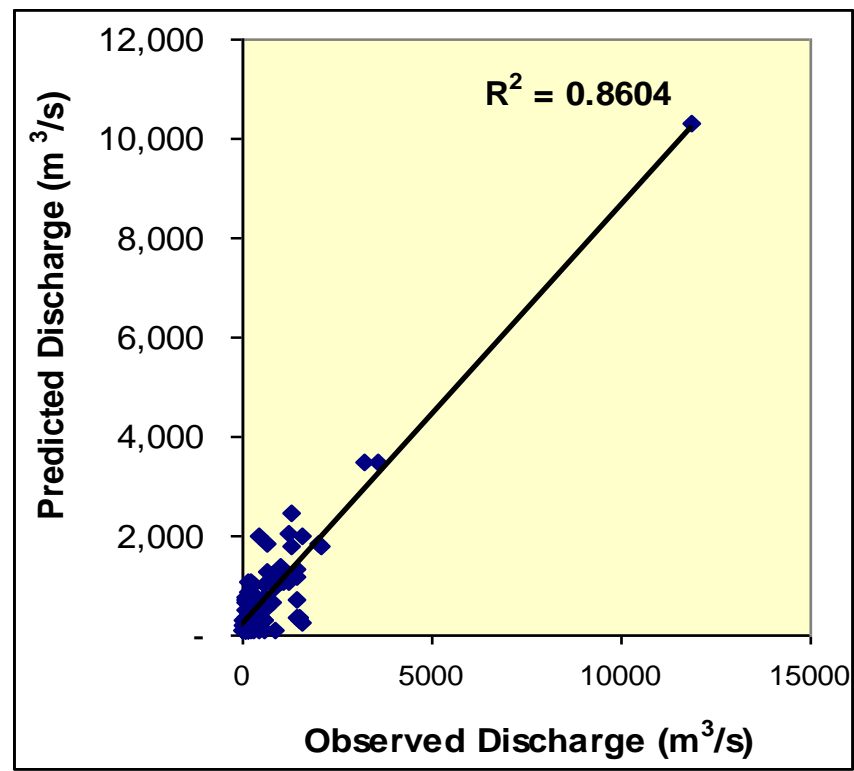

Figure 2.2: Validation of Predicted v/s observed Discharges at Burhanpur

This advance warning of one day ahead plays very significant role in flood management by control of gates further downstream at Hathnur. Throughout the year 2013 the quantity wise and pattern wise, the program gives very good results. Hence this may be further tested for other catchment of Yerli and Hathnur.

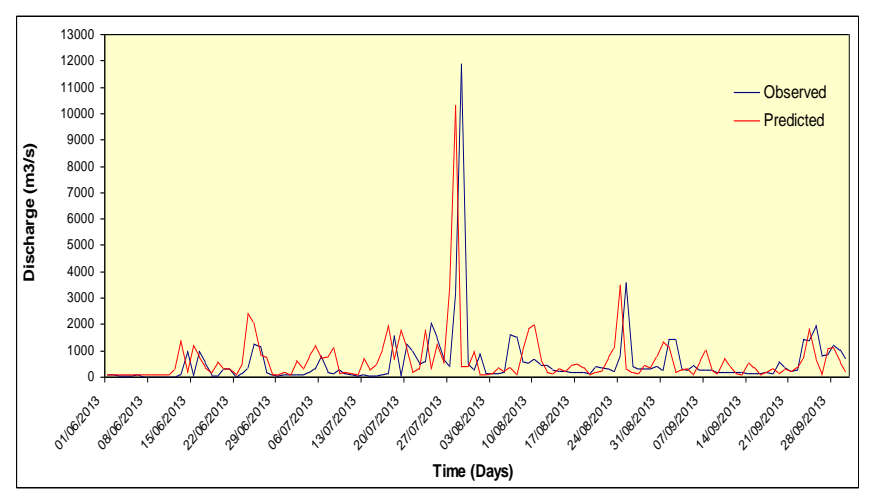

Figure 2.3: Comparison of Predicted and Observed Discharges at Burhanpur Gauging site (Year 2013)

\subsection{Discharge Prediction at Yerli}

There are nine rain gauge stations in Yerlicatchment.Ten years of monsoon rainfall data from Year 2003 to Year 2012 and corresponding discharges at Yerli were taken to generate the regression equation for Yerli Catchment. As discussed in Para 2.1, before establishing the rainfalldischarge regression equation, the daily rainfall series in Yerli Catchment with no lag, one day lag , two day lag and three day lag as compared to daily discharge was correlated to get actual regression equation for the best fitting data having highest coefficient of correlation. Figure 2.4a and $b$ depictscorrelation forone and two days lag respectively. 


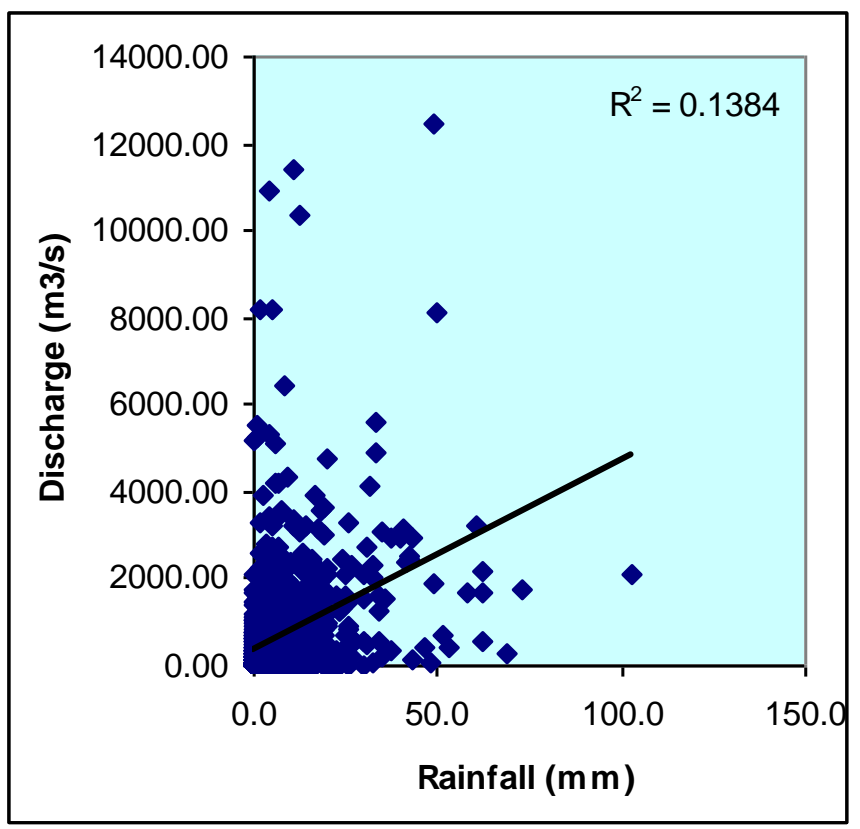

(a)

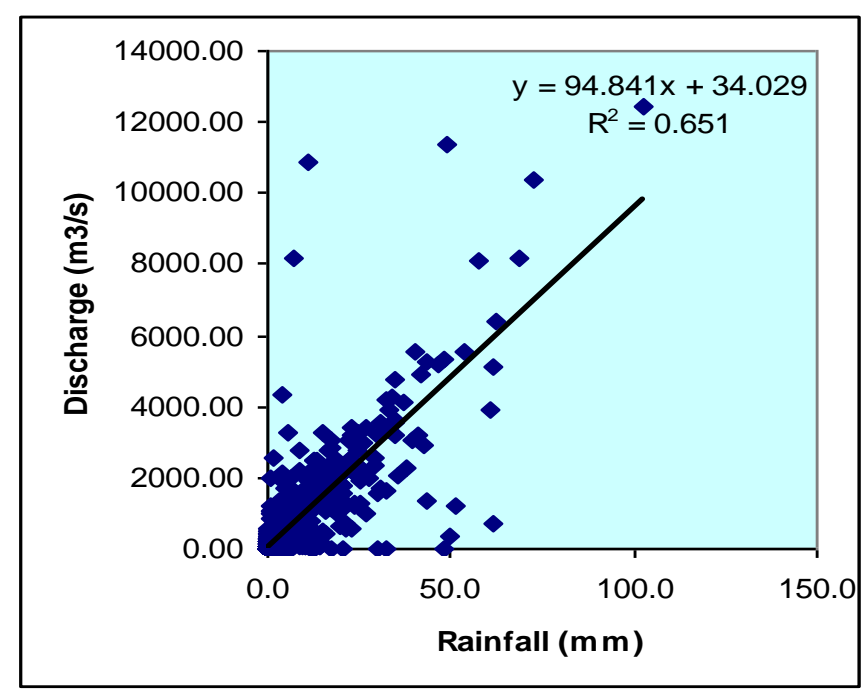

(b)

Figure 2.4: Response of Yerlicatchment at Yerligauging site due to rainfallconsidering (a) one day lag (b) two days lag

As could be seen that the rainfall data in Yerli catchment best matches with the discharge data at Yerli with two days lag (Figure $2.4 \mathrm{~b}$ ) havingcoefficient of correlation $\left(\mathbf{R}^{2}\right)=$ 0.64 It means whenever rainfall occurs in remotest location in Yerli catchment at all eight stations on any two previous days (d-2), its effect will be on day (d). The regression equation thus generated for this set of data for Yerli catchment considering two days lag will be represented as

$: \mathbf{Q}_{\mathrm{Y} 3}=\mathbf{9 4 . 8 4 1} *\left(\left(\mathbf{R}_{\mathrm{bh} 1}+\mathbf{R}_{\mathrm{xm} 1}+\mathbf{R}_{\mathrm{ch} 1+} \mathbf{R}_{\mathrm{an} 1}+\mathbf{R}_{\mathrm{ak} 1}+\mathbf{R}_{\mathrm{te} 1}\right.\right.$ $\left.\left.+R_{\mathrm{sh} 1}+R_{\mathrm{na} 1}+R_{\mathrm{ye} 1}\right) / 9\right)+34.029 \ldots . .(2.2)$

Where $\mathbf{R}_{\text {bh1 }}, \mathbf{R}_{\text {am1 }}, \mathbf{R}_{\text {ch1 }}, \mathbf{R}_{\text {an1 } 1}, \mathbf{R}_{\text {ak1 } 1}, \mathbf{R}_{\text {tel },} \mathbf{R}_{\text {sh1 }}, \mathbf{R}_{\text {na1 }}, \mathbf{R}_{\text {ye1 }}$ representsrainfall at Bhainsdehi (bh) ,Amraoti (am), Chikhalda (ch), Anjangaon (an), Akola (ak), Telhara (te), Shegaon (sh), Nandura (na0 and Yerli (ye) rain gauge stations on $1^{\text {st }}$ day i.e (d-1) while $\mathrm{Q}_{\mathrm{Y} 3}$ represent discharge at Yerli on $3^{\text {rd }}$ day i.e $(d+1)$. The above equation is fed to the program and the same is used to predict discharges at Yerli for the monsoon period of year 2013. The results of the same were validated with the known values of measured discharges. Predictions were made from $1^{\text {st }}$ June to $30^{\text {th }}$ September of the year 2013. It could be observed from Figure 2.5 that the results of discharges so generated by the program gives nearly $85.5 \%$ correct.

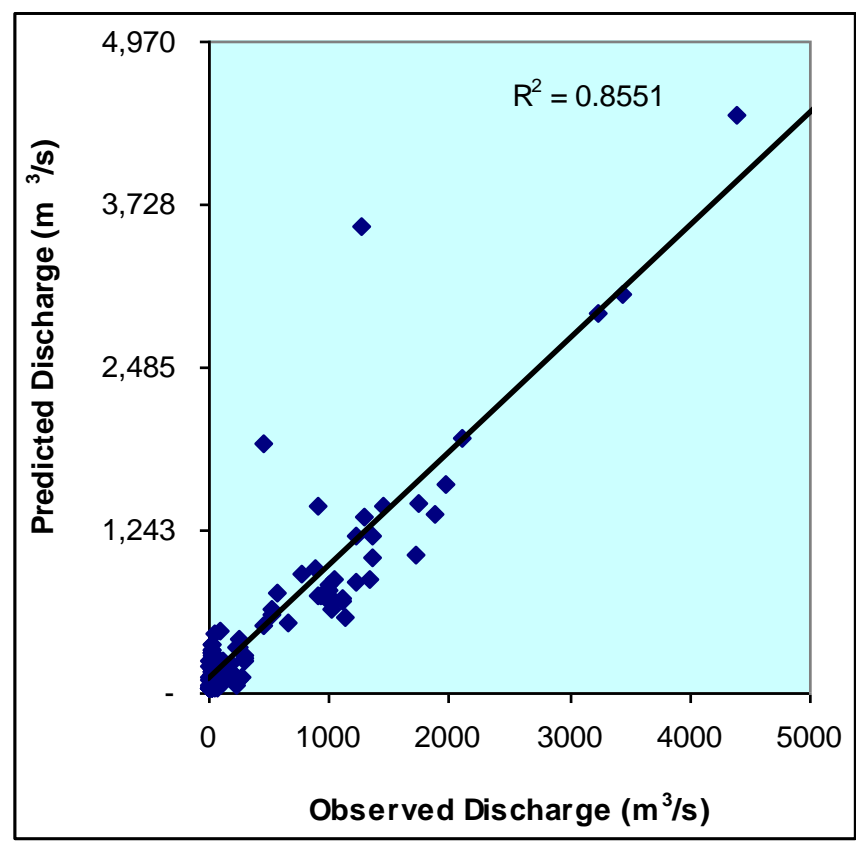

Figure 2.5: Validation of Predicted v/s observed Discharges at Yerli

Comparison of predicted and observed discharges at Burhanpur is also shown as real time flow diagram asFigure 2.6. The graph clearly shows that the pattern of Predicted and Observed discharges at Yerliis in close association of each other with two days lag. It meansfor example we can see from the graph at Figure 2.6 that we have predicted peak discharge of $4580 \mathrm{~m} 3 / \mathrm{s}$ on $28^{\text {th }}$ July 2013 which actually occurred on $30^{\text {th }}$ July 2013 with $5133 \mathrm{~m}^{3} / \mathrm{s}$. If you compare with the scenario of Burhanpur catchment, the rainfall which has measured on $28^{\text {th }}$ July produces a peak discharge at Burhanpur on $29^{\text {th }}$ while that measured on the same day i.e on $28^{\text {th }}$ July in Yerli catchment will produce peak discharge on $30^{\text {th }}$ July i.e one day after the peak discharge occurred in Burhanpur. This advance warning of two days ahead is very much useful to pass on the first peak flow at Burhanpur to Hathnur because there is assured flow which will add to it from yerli on next day. So knowing this fact if our inflow become more and level is crossing the danger level in reservoir we can release water coming from Burhanpur catchment so as to accommodate the flood coming next day from Yerli catchment. Thus the program developed gives freedom to decision maker in flood management by control of gates further downstream at Hathnur. Throughout the year 2013 the quantity wise and pattern wise, the program gives very good results. Hence this may be further tested for whole catchment of Hathnur. 


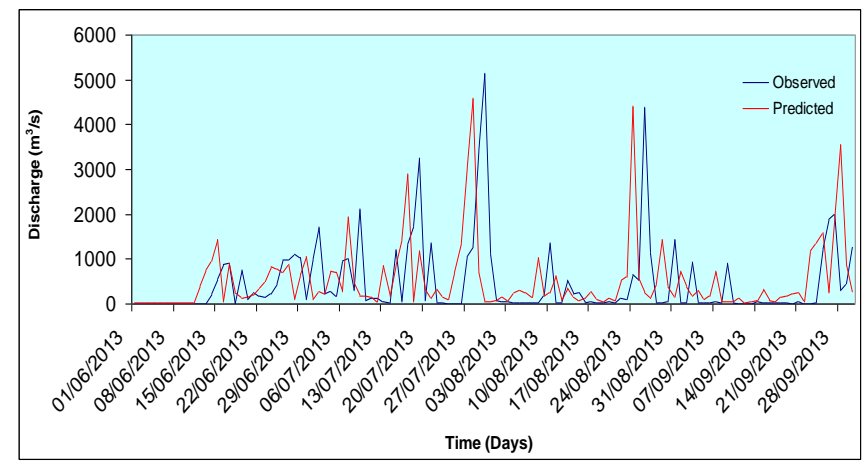

Figure 2.6: Comparison of Predicted and Observed Discharges at Yerli Gauging site

(Year 2013)

\subsection{Discharge Prediction at Intervening Catchment}

There are four rain gauge stations in the intervening catchment between Burhanpur, Yerli and Hathnur viz., Buldhana, Sirpur, Edlabad and Raver. Ten years of monsoon rainfall data from Year 2003 to Year 2012 and corresponding discharges calculated from subtracting effective discharges of Burhanpur and Yerli reaching to Hathnur from corresponding day inflow at Hathnur. A correlation was again developed between this series and four stations rainfall to generate the regression equation for Hathnur (intervening) Catchment. Same as for other two upper catchments, before establishing the rainfall- discharge regression equation, the daily rainfall series with no lag, one day lag, two day lag and three day lag as compared to daily discharge was checked as shown in Figure $2.7 \boldsymbol{a} \& \boldsymbol{b}$.

As could be seen that the rainfall data in Hathnur (intervening) catchment best matches with the discharge data at Hathnur with no lag (Figure 2.7 a). It means when rain occurs in Hathnur (intervening) catchment at all four stations Buldhana, Sirpur, Raver and Edlabad on any day (d), its effect at Hathnur reservoir will be reflected on the same day (d). The regression equation thus generated for this set of data for Hathnur (Intervening) catchment considering no lag will be represented as :

$Q_{\mathrm{Ha} 1}=0.948 *\left(\left(R_{\mathrm{Bu} 1}+R_{\mathrm{Si} 1}+R_{\mathrm{Ra} 1}+\mathbf{R}_{\mathrm{Ed} 1}\right) / 4\right)+93.53$ (2.3)

Where $\mathbf{R}_{\text {Bu1, }}, \mathbf{R}_{\text {Sil }}, \mathbf{R}_{\mathbf{R a 1}}, \mathbf{R}_{\text {Ed1 }}$ representsrainfall at Buldhana $(\mathrm{Bu})$,Sirpur ( $\mathrm{Si}$ ), Raver (Ra) and Edlabad (Ed) rain gauge stations on $1^{\text {st }}$ day while $\mathrm{Q}_{\mathrm{H} a 2}$ represent discharge at Hathnur due to rainfall in intervening catchment on the same day.The above equation is fed to the program and the same is used to predict discharges at Hathnur for the monsoon period of year 2013 .

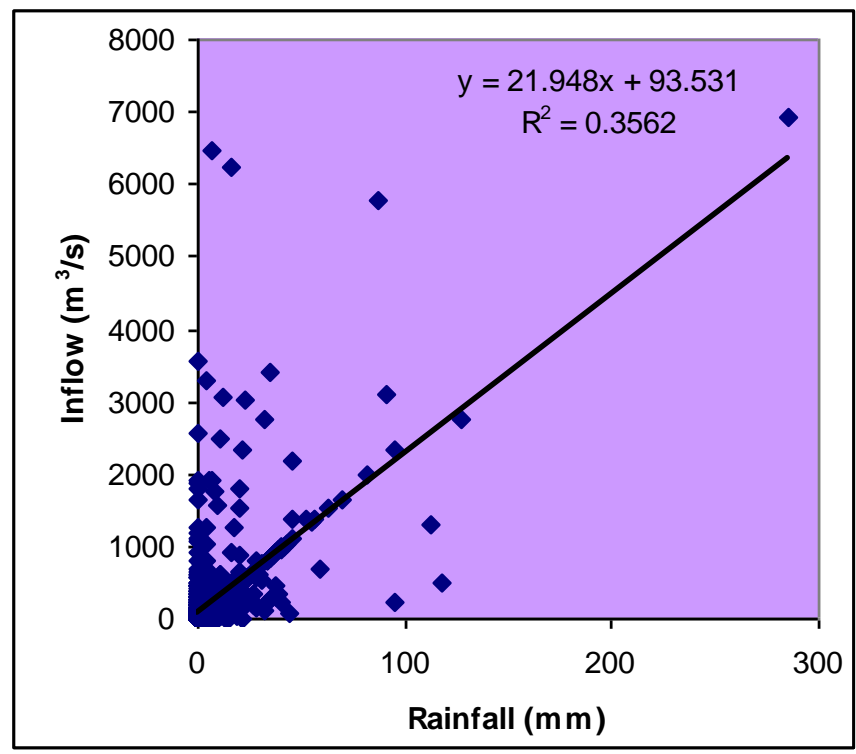

(a)

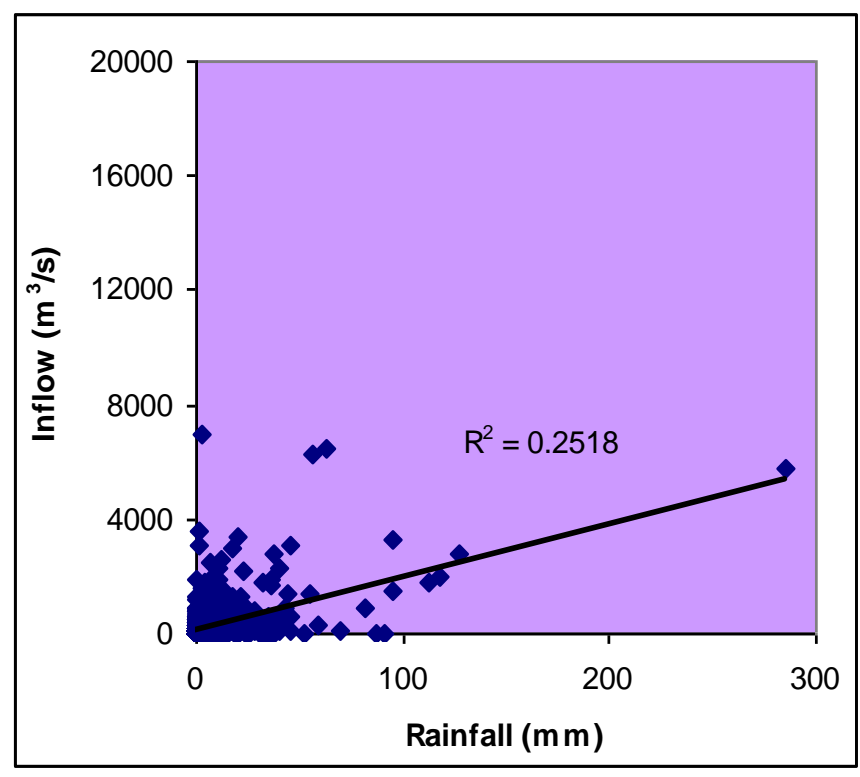

(b)

Figure 2.7: Response of Hathnur intervening catchment at Hathnur Reservoir due to rainfall considering (a) no lag (b) one day lag

In the absence of data for discharges generated due to rainfall in intervening catchment of Hathnurt the results of the above program were validated with the values of computed discharges at Harhnur. Predictions were made from $1^{\text {st }}$ June to $30^{\text {th }}$ September of the year 2013. It could be observed from Figure 2.8 that the results of discharges so generated by the program gives nearly $70 \%$ correct. 


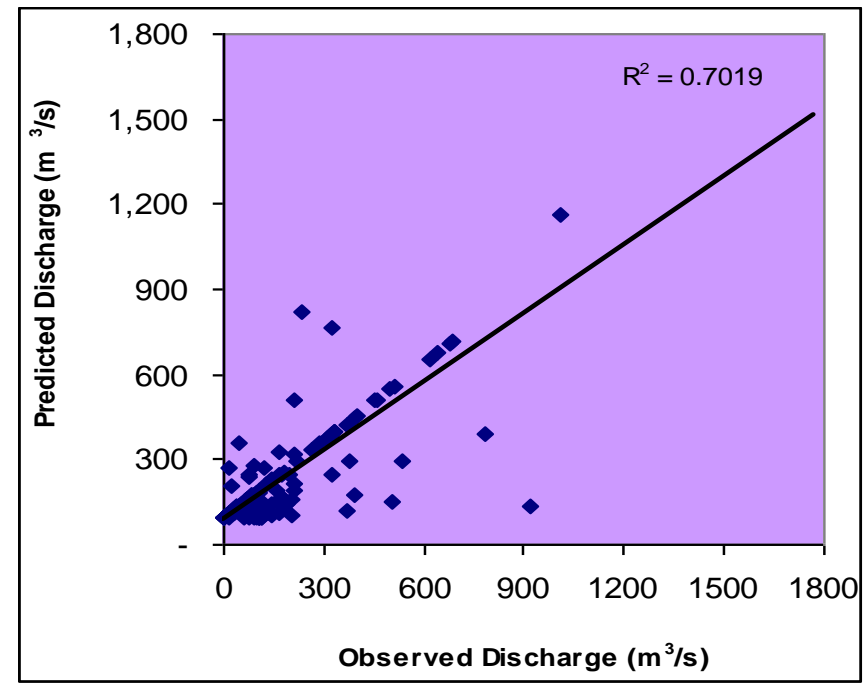

Figure 2.8: Validation of Predicted v/s observed Discharges at Hathnur reservoir due to rainfall in intervening catchment between Burhanpur, Yerli and Hathnur

Comparison of predicted and observed discharges at Hathnur due to rainfall in intervening catchment is also shown as real time flow diagram Figure 2.9. The graph clearly shows that the pattern of Predicted and Observed discharges at Hathnur is in close association of each other without any lag. It meansfor example we can see from the graph at Figure 2.9 that we have predicted peak discharge of $1166 \mathrm{~m}^{3} / \mathrm{s}$ on $28^{\text {th }}$ July 2013 which actually occurred on the same day $28^{\text {th }}$ July 2013 with $1186 \mathrm{~m}^{3} / \mathrm{s}$. This advance warning of same day plays very significant role in flood management by control of gates further downstream at Hathnur. Throughout the year 2013 the quantity wise and pattern wise, the program gives very good results. Hence this may be further tested for development an integrated program to predict inflow at Hathnurtaking discharges form all three catchments Burhanpur, Yerliand Hathnur (intervening).

As rainfall data is simultaneously filled up for each of the sixteen stations at a given time say $8 \mathrm{pm}$, the same will be converted into daily discharge at respective sites automatically using the regression equation generated for that catchment and taking into account the time of travel of water from a particular rainfall station to discharge gauging site. The dedicated computer program will incorporate above phenomenon separately for each of the three catchments viz., Burhanpur, Yerli and Hathnur beyond Burhanpur and Yerli.

The outcome of above program will further integrate all three discharges to predict inflow reaching to the reservoir based on the runoff coefficient of each catchment and time of travel of water from outlet of each catchment uptoHathnur reservoir. There will be three days advance warning of inflow through this program which is really helpful for control of gates of Hathnur Reservoir.

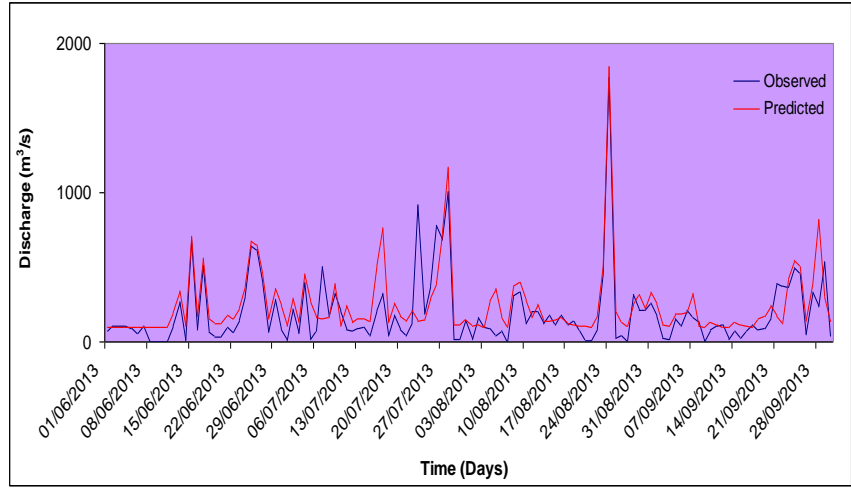

Figure 2.9: Comparison of Predicted and Observed Discharges at Hathnur reservoir due to rainfall in intervening catchment between Burhanpur, Yerli and Hathnur

\section{Estimation of Inflow}

Based on the above concept, program was run with input of daily rainfall at all 16 stations $\left(R_{1}\right.$ to $\left.R_{16}\right)$ from $1^{\text {st }}$ June to $30^{\text {th }}$ September 2013. The discharges thus generated at three sites Burhanpur, $\left(\mathrm{Q}_{\mathrm{Bu}}\right)$, Yerli, $\left(\mathrm{Q}_{\mathrm{Ye}}\right)$ and Hathnur Intervening catchment, $\left(\mathrm{Q}_{\text {Ha.int }}\right)$, were simulated simultaneously to predict daily Inflow at Hathnur, $\left(\mathrm{I}_{\mathrm{Ha}}\right)$ considering one day lag and runoff coefficients at burhanpur, Yerli and Hathnur as $0.5,0.4$ and 0.4 respectively. Following equation was used in the computer program

$$
\begin{aligned}
& \mathbf{I}_{\mathrm{Ha} 2}=\left(\mathbf{R}_{\mathrm{Bu}} * \mathbf{Q}_{\mathrm{Bu} 1}\right)+\left(\mathbf{R}_{\mathrm{Ye}} * \mathbf{Q}_{\mathrm{Ye} 1}\right)+\left(\mathbf{R}_{\mathrm{Ha}(\mathrm{i})} * \mathbf{Q}_{\mathrm{Ha}(\mathbf{i}) 1}\right) \\
& \ldots \ldots \ldots \ldots \ldots \ldots \ldots \ldots \ldots \ldots \ldots \ldots \ldots \ldots \ldots \ldots \ldots \ldots \\
& (3.1)
\end{aligned}
$$

Where $R_{B u} R_{Y e} R_{H a(i}$ ) are runoff coefficient for Burhanpur, Yerli and Hathnur intervening catchments. $\mathrm{Q}_{\mathrm{Bu} 1} \mathrm{Q}_{\mathrm{Ye1}} \mathrm{Q}_{\mathrm{Ha}(\mathrm{i}) 1}$ represents discharges released from Burhanpur, Yerli and Hathnur intervening catchments on first day i.e (d ) and, $\mathrm{I}_{\mathrm{Ha}}$ ${ }_{2}$ is predicted inflow at Hathnur on next day i.e $(d+1)$.

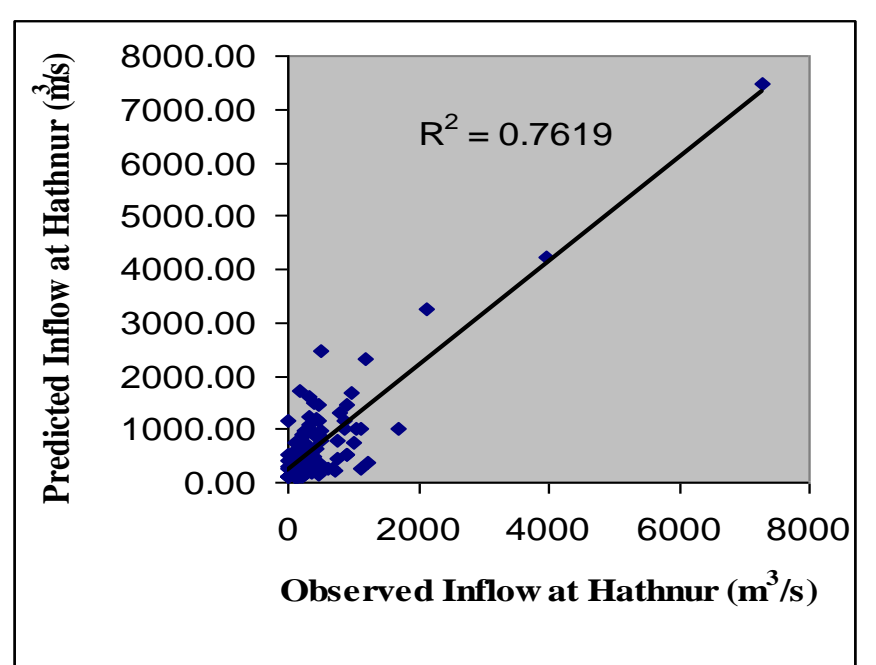

\footnotetext{
Figure 3.1 Performance of Predicted inflow V/s observed Inflow at Hathnur with one day lag
}

Comparison of predicted and observed inflow at Hathnur is shown as real time flow diagram Figure 3.2. The graph clearly shows that the pattern of Predicted and Observed 
discharges at Hathnuris in very close association of each other and also the quantum of inflow is nearly matching with the observed inflow at Hathnur. The graph also depicts that the predictions so made are one day before it occurred at Hathnur.It meansfor example we can see from the graph at Figure 3.2 that we have predicted peak discharge of 7464 $\mathrm{m}^{3} / \mathrm{s}$ on $28^{\text {th }}$ July 2013 which actually occurred on $29^{\text {th }}$ July 2013 with $7267 \mathrm{~m}^{3} / \mathrm{s}$. This one day before prediction is actually three day ahead because the discharges are the generated discharges based on two days ahead rainfall in Yerli catchment. This warning of three days in advance plays very significant role in flood management by control of gates further downstream at Hathnur. Throughout the year 2013 the quantity wise and pattern wise, the program gives very good results. Hence this may be further tested for development an integrated program to make decision about control of gates so as to release water in systematic manner.

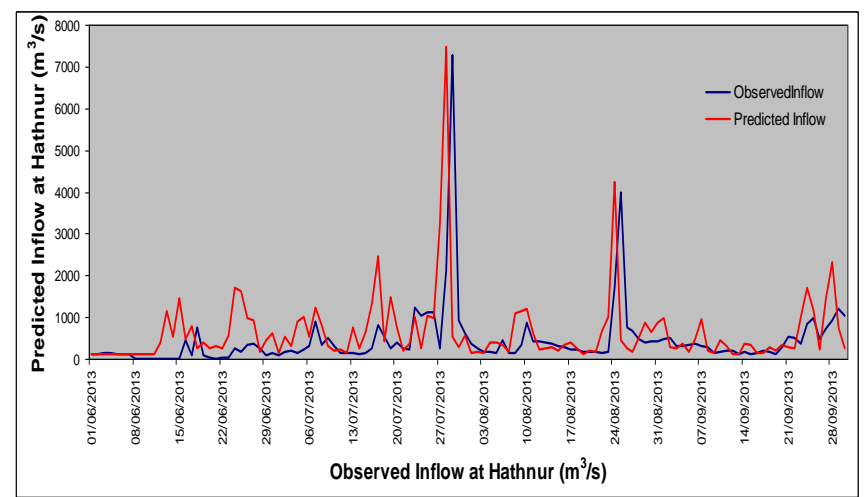

Figure 3.2 Comparison of Predicted and Observed Inflow at Hathnur due to rainfall in catchment of Burhanpur, Yerli and Hathnur (Intervening) for the monsoon period of Year 2013

\section{CONCLUSIONS}

The results yielded by using DSS are satisfactory.Hence it can be concluded that DSS can be used for predicting discharge and inflow of water coming to the reservoir by simply using Rainfall data. By applying Regression analysis on previous Rainfall-Discharge Data, the new values of Discharge are predicted and different patterns of data can be found. Flash floods can be avoided using this system.

\section{ACKNOWLEDGEMENT}

We would like to thank Director, CWPRS, Pune,Prof. Sunil Sangve HoD, Computer Department, and Prof. Renuka Suryawanshi, ZCOER, Pune, Maharashtra, Indiafor their support and invaluable guidance that has led this project to its completion.

\section{REFERENCES}

[1] https://en.wikipedia.org/wiki/Decision_support_system [2]Liao Shu-Hsien, 2005, "Expert system methodologies and applications-a decade review from 1995 to 2004"'Elsevier, 28, 93-103.

[3].Ladhe P P, Sangita Sau, Deshmukh A, "Sedimentation:A critical problem of major irrigation projects:-A case study of Hatnur Dam in Jalgaon district, Maharashtra",Research and Evaluation -ISSN-0974-2832

[4].Alexandra P. Jacquin a, Asaad Y. Shamseldin,2006, "Development of rainfall-runoff models using TakagiSugeno fuzzy inference systems, Journal of Hydrology, 329, 154-173

[5]. JoshiG. I. \& Patel A. S., 2010, "Flood Water Surface Profile in Tapi River- Surat", Journal of Rangeland Science, Vol. 1.

\section{BIOGRAPHIES}

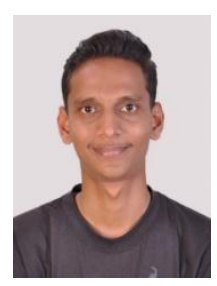

OMKAR POTEKAR

Author is currently pursuing B.E.(Comp) from ZCOER, Pune

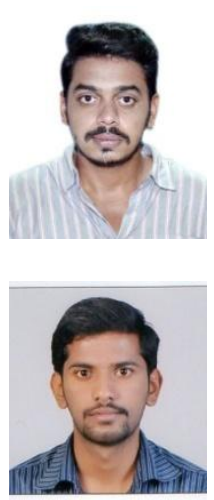

\section{SIDDHARTH ROMAN}

Author is currently pursuing B.E.(Comp) from ZCOER, Pune

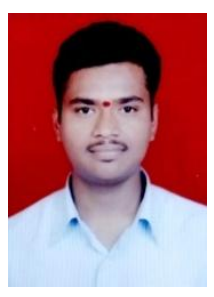

SWAPNIL DHUMAL

Author is currently pursuing B.E.(Comp) from ZCOER, Pune

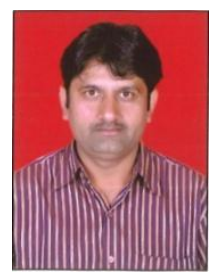

\section{PRATAP SINGH SOLANKI}

Author is well-known Scientist-B working at CWPRS, Pune. He works in the field of software development and management. 